\title{
The Analysis of Inequality on Economic Growth in Indonesia
}

DOI: https://doi.org/10.47175/rissj.v1i3.103

\section{| Fitrawaty | \\ Universitas Negeri Medan, Indonesia}

fitrawaty@unimed.ac.id

\begin{abstract}
Development is carried out to improve people's welfare, so that economic growth and an even distribution of income are needed. Rapid economic growth that is not balanced with equal distribution, will lead to regional imbalances. The objectives of this study are to; (1) to analyze the factors causing inequality on economic growth in all provinces in Indonesia; (2) to analyze the largest contributor to development inequality between provinces in Indonesia, (3) to form a model of development inequality and economic growth for each province and Indonesia (4) to generat ideas or ideas for solutions to control development inequality and economic growth in Indonesia. The variables studied are the wiliamson index, human development index, unemployment and the General Allocation Fund for each province in Indonesia in 2010-2017. The data observed are primary data and secondary data from various related agencies, such as Bank Indonesia, Statistics Indonesia, Ministry of National Development Planning of the Republic of Indonesia and Ministry of Finance Indonesia. Before being analyzed, the data will pass through the next classical assumption test stage with the Panel Data Model. The results showed that the unemployment rate had a negative and significant effect, while General Allocation Fund and HDI had a positive and significant effect on the level of inequality in Indonesia.

KEYWORDS

Wiliamson Index; unemployment; General Allocation Fund; HDI; panel data model
\end{abstract}

\section{INTRODUCTION}

Since the early days of independence, the Indonesian nation has had great concern for the creation of a just and prosperous society as contained in the fourth paragraph of the preamble to the 1945 Constitution. Development programs implemented so far have always paid great attention to efforts to alleviate poverty because basically development which is carried out aims to improve community welfare. Even so, the problem of poverty until now has been a persistent problem. Actually there have been many poverty alleviation programs carried out by the government, but they have not brought significant changes. The development strategy developed by the Indonesian nation so far is based on high economic growth. The economic growth which is considered high is not followed by an even distribution of income among all groups of society. So that there is a trade-off between growth and equity, hereinafter known as inequality (Prawoto, 2009).

One method used to measure the level of regional economic inequality between districts or cities is the Williamson Index. Williamson in (Kuncoro, 2004) examines the relationship between regional disparities with the level of economic development, using economic data 
from developed and developing countries. Regional economic disparities became greater and development was concentrated in certain areas. In a more 'mature' stage of economic growth, there is a balance between regions and disparities are significantly reduced.

Various attempts have been made by the government to reduce the level of inequality, but have not yet been fully resolved. Table 1 provides an overview of development inequality and economic growth using the Williamson index and several factors that influence it.

Table 1. Development of Williamson Index, HDI, Unemployment, GRDP and General Allocation Fund of Provinces in Indonesia in 2017

\begin{tabular}{|l|l|l|c|l|}
\hline \multicolumn{1}{|c|}{ Province } & WI & HDI & Unemployment & $\begin{array}{l}\text { General Allocation } \\
\text { Fund (Rupiah) }\end{array}$ \\
\hline Aceh & 0,241228 & 70,6 & 6,98 & 1.930 .152 .204 \\
\hline $\begin{array}{l}\text { North Sumatra } \\
\text { Sumatera Utara }\end{array}$ & 0,356276 & 70,57 & 6,005 & 2.493 .484 .717 \\
\hline West Sumatera & 0,228882 & 71,24 & 5,69 & 1.953 .594 .421 \\
\hline Bangka Belitung & 0,17971 & 69,99 & 4,12 & 969.535 .866 \\
\hline Riau Islands & 0,276648 & 74,45 & 6,8 & 1.043 .954 .307 \\
\hline West Java & 0,492105 & 70,69 & 8,355 & 2.879 .143 .808 \\
\hline Central Java & 0,456634 & 70,52 & 4,36 & 3.520 .364 .822 \\
\hline $\begin{array}{l}\text { Special Region of } \\
\text { Yogyakarta }\end{array}$ & 0,337916 & 78,89 & 2,93 & 1.312 .215 .989 \\
\hline Banten & 0,427188 & 71,42 & 8,515 & 1.043 .042 .265 \\
\hline Bali & 0,188633 & 74,3 & 1,38 & 1.234 .481 .776 \\
\hline West Nusa Tenggara & 0,264798 & 66,58 & 3,59 & 1.416 .022 .952 \\
\hline East Kalimantan & 0,402097 & 75,12 & 7,73 & 642.101 .957 \\
\hline North Kalimantan & 0,069147 & 69,84 & 5,355 & 1.163 .384 .773 \\
\hline North Sulawesi & 0,347333 & 71,66 & 6,65 & 1.340 .353 .014 \\
\hline South Sulawesi & 0,410733 & 70,34 & 5,19 & 2.266 .264 .600 \\
\hline South East Sulawesi & 0,315817 & 69,86 & 3,22 & 1.493 .557 .900 \\
\hline Gorontara & 0,0584 & 67,01 & 3,965 & 971.731 .886 \\
\hline West Sulawesi & 0,283176 & 64,3 & 3,095 & 977.903 .640 \\
\hline Maluku & 0,212898 & 68,19 & 8,53 & 1.465 .641 .669 \\
\hline Papua & 0,864547 & 59,09 & 3,79 & 2.570 .118 .273 \\
\hline
\end{tabular}

Source: Statistics Indonesia (2018), Ministry of Finance Indonesia (2018)

From Table 1, only Papua Province has a high level of inequality criteria, the provinces that have moderate inequality are; North Sumatra, West Java, Central Java, Banten, East Kalimantan and South Sulawesi, while the provinces with low levels of inequality are; Aceh, West Sumatera, Bangka Belitung, Riau Islands, Special Region of Yogyakarta, Bali, West Nusa Tenggara, North Kalimantan, North Sulawesi, West Sulawesi, Gorontalo and Maluku. Papua and Central Java have the highest levels of inequality, receive relatively high General Allocation Fund compared to other provinces in Indonesia. The description of these two indicators briefly explains that the provision of General Allocation Fund, which is expected to reduce inequality, has not succeeded in reducing inequality.

Inequality in development and economic growth is also influenced by population growth, both in terms of quantity and quality of the population. The quality of an area is 
highly dependent on the quality of human resources (HR). The indicator used to measure the quality of human resources is the Human Development Index (HDI). HDI can also be interpreted as building one's abilities through improving the level of health, knowledge or education and skills. In summary, Ranis and Stewart (2000) define human development as an improvement in one's condition so as to enable a longer life as well as being healthier and more meaningful. According to UNDP (2013), Maipita (2013) Human Development Index (HDI) is a comparative measure of life expectancy, literacy, education and living standards for all countries around the world.

\section{RESEARCH METHODS}

This study will observe the level of growth inequality measured by the Williamson index (WI), Unemployment Rate, General Allocation Funds and Human Development Index (HDI) between provinces in Indonesia during 2010 - 2017.

Data collection carried out in this study is the documentation method, namely the collection of data from various related sources, because this study uses secondary data, data is taken from Bank Indonesia, Statistics Indonesia, and other sources related to the research.

The method used by researchers is regression using panel data (pooled data) or what is called the panel data regression model. Considering that panel data is a combination of time series data and cross section data (between individuals / spaces), in the panel data model, the same cross section unit is surveyed over time (Gujarati, 2003) and panel data models can be written as:

$Y_{\text {it }}=\alpha+\beta X_{\text {it }}+\varepsilon_{\text {it }} ; \mathrm{i}=1,2, \ldots, N ; t=1,2, \ldots ., \mathrm{T}$

Where :

$\mathrm{i}=$ the number of observations

$\mathrm{t}=$ time

i $\mathrm{x} \mathrm{t}=$ the amount of panel data

In the regression model estimation method using panel data, it can be done through three approaches, including the Pooled Least Square (PLS) method, the Fixed Effect Model (FEM), and the Random Effect Model (REM). ).

Panel data analysis in this study was used to analyze the impact of population fluctuations, regional minimum wages, rice prices, economic growth rates on the inflation rate of districts and municipalities in North Sumatera. From the variables used, a research model can be formed as follows:

$Y_{i t}=\alpha_{i t}+\beta_{1} X_{1}+\beta_{2} X_{2}+\beta_{3} X_{3}+\beta_{4} X_{4}+\varepsilon_{i t}$

Dimana:

$\mathrm{Y}_{\mathrm{it}} \quad=$ Level of Inequality (Williamson Index)

$\mathrm{X}_{1} \quad=$ Unemployment Rate $(\%)$

$\mathrm{X}_{2} \quad=$ HDI

$\mathrm{X}_{3} \quad=$ General Allocation Fund (Rp Million)

$\beta_{1}, \beta_{2}, \beta_{3}, \beta_{4} \quad=$ Regression coefficient

$\alpha_{\mathrm{it}} \quad=$ Intercept

$\varepsilon_{\mathrm{it}} \quad=$ Error

\section{Chow Test}

The Chow test is a test to compare the Fixed Effect or Common Effect models which is more precise for estimating a panel data (Gujarati, 2003). The hypothesis in the Chow Test is: 
$\mathrm{H}_{0}$ : Common Effect Model (CEM) or Pooled Least Square (PLS)

$\mathrm{H}_{1}$ : Fixed Effect Model (FEM)

The basis for rejection of the above hypothesis is to compare the F-statistic calculation with the F-table. If the F-statistic is greater than the F-table, then $\mathrm{H}_{0}$ is rejected, which means that the most appropriate model to use is the Fixed Effect Model. (Widaryono, 2009).

\section{Hausman Test}

The test to compare the Fixed Effect model with the random effect was developed by Hausman (Widaryono, 2007), based on the idea that LSDV in the Fixed Effect method and the GLS method is efficient while the OLS method is inefficient, with the alternative of the OLS method being efficient and GLS inefficient. The null hypothesis $\left(\mathrm{H}_{0}\right)$ is that the estimation results of the two are not different.

If the calculated Hausman value is greater than the critical value of the Chi-squares table, the Fixed Effect model is better. Conversely, if the Hausman statistical value is smaller than the critical value, then the random effect model is better (Widaryono, 2009).

\section{Lagrange Multiplier Test}

The Lagrange Multiplier (LM) test is a test to compare the Random Effect or Common Effect model that is most appropriate to estimate panel data. The Lagrange Multiplier test was developed by Breusch-Pagan. The Breusch-Pagan method for the Random Effect significance test is based on the residual value of the PLS method.

The LM test is based on the chi-squares distribution with the degree of freedom of the number of independent variables. If the LM statistical value is greater than the critical value of the chi-squares statistic, then $\mathrm{H}_{0}$ is rejected, meaning that the appropriate estimation model for panel data regression is the Random Effect model.

\section{Statistical Test Analysis}

Statistical Test $F$

The F statistical test is used to test the effect of the independent variables simultaneously on the dependent variable. This test is based on the null hypothesis $\left(\mathrm{H}_{\mathrm{o}}\right)$ to be tested, namely whether all the parameters in the model are equal to zero, or $H_{0}: \alpha_{1}=\alpha_{2}=\ldots=\alpha_{n}$ $=0$, meaning whether all independent variables are not significant explanations of the variables dependent. And for $\mathrm{H}_{\mathrm{a}}$ : at least one of $\alpha_{\mathrm{n}} \neq 0$.

To test these two hypotheses is to compare the F-count value with the F-table value. If the F-count value is greater than the F-table value, the alternative hypothesis is that all independent variables jointly affect the dependent variable.

\section{Individual Significance Test (t-Test)}

This test is to see the influence of each independent variable on the dependent variable. The $t$ statistical test is basically to show how far the influence of one independent variable is in explaining the variation of the dependent variable. The null hypothesis $\left(\mathrm{H}_{\mathrm{o}}\right)$ to be tested is whether a parameter $\left(\alpha_{1}\right)$ is equal to zero, or $H_{0}: \alpha_{1}=0$, meaning that an independent variable is not a significant explanation for the independent variable. The alternative hypothesis $\left(\mathrm{H}_{\mathrm{a}}\right)$ that the parameter of a variable is not equal to zero, or $\mathrm{H}_{\mathrm{a}}: \alpha_{1} \neq$ 0 , meaning that the variable is a significant explanation for the dependent variable.

The way to do the t test is to compare the t-statistic value with the t-table value. While the $t$ test is formulated as follows: 
Where :

$$
t=\frac{r \sqrt{n-2}}{\sqrt{1-r^{2}}}
$$

$\mathrm{t}=\mathrm{t}$-count

$\mathrm{r}=$ Correlation coefficient

$\mathrm{n}=$ Number of samples

If the value of the t-statistic is greater than the t-table, then the alternative hypothesis $\left(\mathrm{H}_{\mathrm{a}}\right)$ is not rejected, which means that an independent variable individually affects the dependent variable, in other words, if $\mathrm{H}_{\mathrm{o}}$ is rejected, it means that there is a significant effect of the independent variable on the dependent variable.

\section{Determinant Coefficient Test $\left(\boldsymbol{R}^{2}\right)$}

To measure how far the model's ability to explain the dependent variable is done by calculating the determinant coefficient $\left(\mathrm{R}^{2}\right)$. The value of the determinant coefficient is between zero and one, or $0<\mathrm{R}^{2}<1$. According to Gujarati (2003), if $\mathrm{R}^{2}=0$, the diversity of $\mathrm{Y}$ cannot at all be explained by the diversity of $\mathrm{X}$. Conversely, if $\mathrm{R}^{2}=100 \%$, the diversity of $\mathrm{Y}$ can be explained by diversity. $\mathrm{X}$, all observation points are on the regression line.

To compare the two $\mathrm{R}^{2}$, the number of independent variables in the model must be taken into account, that is, by considering the alternative coefficient of determination, otherwise known as adjusted $\mathrm{R}^{2}$. "Adjusted" here means adjusted to the degrees of freedom.

\section{Classic Assumption Test}

Before analyzing data with the Data Panel Model, several tests were carried out on the data. Classical assumption tests are statistical requirements that must be met in multiple linear regression analysis based on Ordinary Least Square (OLS). The classic assumption tests that are often used are multicollinearity test, heteroscedasticity test, autocorrelation test. The OLS method will produce an estimator that is Best Linear Un] Estimator (BLUE) if the model used meets the following assumptions:

1. $E\left(\varepsilon_{i}\right)=0$, untuk setiap $I$, the mean value of the confounder's error is zero for $i=1,2$, $\ldots, \mathrm{n}$

2. $\operatorname{Cov}(-i,-j)=0, i \neq j$, there is no autocorrelation between confounding errors.

3. $\operatorname{Var}\left(E_{\mathrm{i}}\right)=\sigma^{2}$, Same variance for all confounding errors (assuming homoscedasticity).

4. $\operatorname{Cov}\left({ }^{1}{ }^{{ }^{* a}}{ }^{2 n}\right)=\operatorname{Cov}\left({ }^{a} I^{a_{3 n}}\right)=0$, there is no correlation between any independent variable $X$ and confounding error $X_{i}$.

5. There is no multiple collinearity (multicollinearity) between the independent variables. Autocorrelation test is defined as the correlation between observation members in Serial correlation or between observation members of various objects or spaces (spatial correlation). Autocorrelation occurs due to economic data slowness factors, specification bias to exclude relevant variables from the model, functional form specification bias, grace period or lag, data manipulation, data transformation, and non-stationarity in the model (Manurung, et al, 2005). The method used to detect autocorrelation is done in four ways, namely the Graph Method, the Run Test, the Durbin-Watson d Test, and the BreuschGodfrey Test. The method used in this study is the Durbin-Watson d Test.Autoregression or AR, namely: $\varepsilon_{t}=\rho \varepsilon_{t-1}+v_{t}$ obtained from the rho coefficient value as follows: 


$$
\begin{aligned}
& \rho=\frac{\sum_{2}^{T} \varepsilon_{t} \varepsilon_{t-1}}{\sum_{2}^{T} \varepsilon^{2}{ }^{2}-1} \text { or } \rho=1-0.5 \delta \text { so } \delta \approx 2(1-\rho) \\
& d=\frac{\sum_{2}^{T}\left(\varepsilon_{t}-\varepsilon_{t-1}\right)^{2}}{\sum_{1}^{T} \varepsilon_{t^{2}}}
\end{aligned}
$$

If $-1 \leq \rho \leq 1$ dan $d \approx 2(1-\rho)$ then the statistical value limit $\mathrm{d}$ is $0 \leq d \leq 4$

If $\rho=0$ maka $d \approx 2$, means there is no serial correlation.

If $\rho=+1$ maka $d \approx 0$, means there is a perfect positive serial correlation.

If $\rho=-1$ maka $d \approx 4$, means a perfectly negative serial correlation occurs.

Multicollinearity test, is there is a perfect linear relationship between the independent variables of a regression model. (Firdaus, 2011). Multicollinearity occurs because, among others, the data collection method used limits the value of the regressor variables, model constraints on the observed population, model specifications, determines the number of independent variables that is more than the number of observations, and time series data. The multicollinearity in the study is to look at the variance inflating factor (VIF) value, namely:

$$
V I F=\frac{1}{1-r_{12}^{2}}
$$

Where:

$r_{12}{ }^{2}=$ correlation coefficient between $\mathrm{X}_{1}$ and $\mathrm{X}_{2}$

VIF indicates that the variance is estimated to increase due to the presence of multicollinearity. The coefficient of the regression model is directly proportional to the VIF.

Heteroscedacity test, testing whether the disturbance / error terms that appear in the regression function have the same variance or not. A good model of analysis is if the variance of the disturbance is the same (homoscedastic). The assumption of homoscedasticity from random shocks is the difference or spread or equal scedasticity or equal or homo or equal variance $\left[\sigma^{2}\right]$. Symbolically homoscedasticity and heteroscedasticity are respectively written as follows:

$$
\begin{array}{ll}
E\left[\varepsilon_{i}^{2}\right]=\sigma^{2} & \mathrm{t}=1,2, \ldots, \mathrm{T} \\
E\left[\varepsilon_{i}^{2}\right]=\sigma_{i}^{2} & \mathrm{t}=1,2, \ldots, \mathrm{T}
\end{array}
$$




\section{RESULTS AND DISCUSSION}

Forming Models inflation of North Sumatera

\section{Chow Test}

Table 2. Chow Test Results

\begin{tabular}{|c|c|c|c|c|}
\hline \multicolumn{5}{|c|}{$\begin{array}{l}\text { Redundant Fixed Effects Tests } \\
\text { Pool: DATAPANEL } \\
\text { Test period fixed effects }\end{array}$} \\
\hline Effects Test & & Statistic & d.f. & Prob. \\
\hline Period F & & 0.768442 & $(10,29)$ & 0.6572 \\
\hline \multicolumn{5}{|c|}{$\begin{array}{l}\text { Period fixed effects test equation: } \\
\text { Dependent Variable: LOG(I?) } \\
\text { Method: Panel EGLS (Period weights) } \\
\text { Date: 10/05/19 Time: 00:17 } \\
\text { Sample: } 20072017 \\
\text { Included observations: } 11 \\
\text { Cross-sections included: } 4 \\
\text { Total pool (balanced) observations: } 44 \\
\text { Use pre-specified GLS weights }\end{array}$} \\
\hline Variable & Coefficient & Std. Error & $\mathrm{t}$-Statistic & Prob. \\
\hline $\begin{array}{l}\text { C } \\
\text { LOG(PENDUDUK?) } \\
\text { LOG(UMR?) } \\
\text { LOG(BERAS?) } \\
\text { LOG(PE?) }\end{array}$ & $\begin{array}{l}-11.42864 \\
4.348638 \\
-5.087282 \\
5.219694 \\
-0.153531\end{array}$ & $\begin{array}{l}8.157158 \\
0.966127 \\
1.570173 \\
1.033354 \\
0.248995\end{array}$ & $\begin{array}{l}-1.401057 \\
4.501104 \\
-3.239950 \\
5.051218 \\
-0.616603\end{array}$ & $\begin{array}{l}0.1691 \\
0.0001 \\
0.0024 \\
0.0000 \\
0.5411\end{array}$ \\
\hline \multicolumn{5}{|c|}{ Weighted Statistics } \\
\hline $\begin{array}{l}\text { R-squared } \\
\text { Adjusted R-squared } \\
\text { S.E. of regression } \\
\text { F-statistic } \\
\text { Prob(F-statistic) }\end{array}$ & $\begin{array}{l}0.572553 \\
0.528712 \\
1.028581 \\
13.05984 \\
0.000001\end{array}$ & \multicolumn{2}{|c|}{$\begin{array}{l}\text { Mean dependent var } \\
\text { S.D. dependent var } \\
\text { Sum squared resid } \\
\text { Durbin-Watson stat }\end{array}$} & $\begin{array}{l}14.77056 \\
5.826445 \\
41.26118 \\
0.463019\end{array}$ \\
\hline \multicolumn{5}{|c|}{ Unweighted Statistics } \\
\hline $\begin{array}{l}\text { R-squared } \\
\text { Sum squared resid }\end{array}$ & $\begin{array}{l}0.233837 \\
47.20107\end{array}$ & $\begin{array}{l}\text { Mean de } \\
\text { Durbin-I }\end{array}$ & $\begin{array}{l}\text { endent var } \\
\text { atson stat }\end{array}$ & $\begin{array}{l}12.64401 \\
0.510817\end{array}$ \\
\hline
\end{tabular}

From the results of the chow test data processing presented in table 2 above, the Prob value is obtained. Cross-section $\mathrm{F}$ is 0.000001 , which means that the value obtained is $<0.05$, so it can be concluded that the Fixed Effect model is more precise than the Common Effect model. 
Panel Data Regression Estimation Results with the Fixed Effect Model Method

The test results of this research model using the Eviews 8.1 program tool. This research deals with regency / city individual behavior which is regressed in a system (multi equation). In this estimator, the estimated equation consists of 4 districts / cities with an annual observation time (Annual) from 2010-2017.

Table 3 presents the results of data processing using the Fixed Effect method. From the estimation results, the next research model will be analyzed the statistical significance test and a priori economic test analysis (direction and significance).

Table 3. The Estimation Results of Fixed Effect Model

\begin{tabular}{|c|c|c|c|c|}
\hline \multicolumn{5}{|c|}{$\begin{array}{l}\text { Dependent Variable: LOG(I?) } \\
\text { Method: Pooled EGLS (Period weights) } \\
\text { Date: } 10 / 04 / 19 \text { Time: } 22: 22 \\
\text { Sample: } 20072017 \\
\text { Included observations: } 11 \\
\text { Cross-sections included: } 4 \\
\text { Total pool (balanced) observations: } 44 \\
\text { Linear estimation after one-step weighting matrix }\end{array}$} \\
\hline Variable & Coefficient & Std. Error & $\mathrm{t}$-Statistic & Prob. \\
\hline C & -91.76667 & 43.31051 & -2.118808 & 0.0428 \\
\hline LOG(PENDUDUK?) & 8.429256 & 2.539722 & 3.318968 & 0.0024 \\
\hline LOG(UMR?) & -2.302758 & 2.412742 & -0.954415 & 0.3478 \\
\hline LOG(BERAS?) & 4.738640 & 1.415063 & 3.348713 & 0.0023 \\
\hline LOG(PE?) & -1.045921 & 0.794842 & -1.315884 & 0.1985 \\
\hline \multicolumn{5}{|l|}{ Fixed Effects (Period) } \\
\hline $2007-C$ & 2.812586 & & & \\
\hline $2008-C$ & 3.782814 & & & \\
\hline $2009-C$ & 1.300654 & & & \\
\hline $2010-C$ & 2.070427 & & & \\
\hline $2011-C$ & 0.612189 & & & \\
\hline $2012-C$ & -0.190642 & & & \\
\hline $2013-C$ & 0.073648 & & & \\
\hline $2014-C$ & -1.357918 & & & \\
\hline $2015-C$ & -2.672346 & & & \\
\hline $2016-C$ & -2.674637 & & & \\
\hline \multirow[t]{2}{*}{$2017-C$} & -3.756776 & & & \\
\hline & \multicolumn{4}{|c|}{ Effects Specification } \\
\hline \multicolumn{5}{|c|}{ Period fixed (dummy variables) } \\
\hline & \multicolumn{4}{|c|}{ Weighted Statistics } \\
\hline R-squared & 0.662092 & \multirow{5}{*}{\multicolumn{2}{|c|}{$\begin{array}{l}\text { Mean dependent var } \\
\text { S.D. dependent var } \\
\text { Sum squared resid } \\
\text { Durbin-Watson stat }\end{array}$}} & 14.77056 \\
\hline Adjusted R-squared & 0.498964 & & & 5.826445 \\
\hline S.E. of regression & 1.060547 & & & 32.61805 \\
\hline F-statistic & 4.058723 & & & 0.316876 \\
\hline Prob(F-statistic) & 0.000702 & & & \\
\hline
\end{tabular}




\begin{tabular}{|llll|}
\multicolumn{4}{|c|}{ Unweighted Statistics } \\
\hline \hline R-squared & 0.377409 & Mean dependent var & 12.64401 \\
Sum squared resid & 38.35601 & Durbin-Watson stat & 0.360231 \\
\hline \hline
\end{tabular}

Source: Panel data output results processed with Eviews 8.1

Based on the results of data processing in Table 3 above, it can be written that in general the Inflation Equation Model in North Sumatera is as follows:

LOG $($ Inflation $)=-91.76667+8.429256$ LOG (population) -2.302758 LOG (Regional Minimum Wage) + 4.738640 LOG (Price of Rice) -1.045921 LOG (EG).

The constant value of the equation model is - 91.7, meaning that if the independent variables of the Population, Regional Minimum Wage, Rice Price, and Economic Growth are assumed to be zero, then the inflation rate of North Sumatera Province will decrease by $91.7 \%$.

\section{Statistical Significance Test Analysis}

Based on the panel data regression estimation output with the fixed effect method above, we can perform statistical test analysis as follows:

\section{Partial Test (t-test)}

From the table of processing results using Eviews 8.1 above, it can be seen that the independent variables, namely the Population and Price of Rice, have a significant effect on the 5\% significance level on the dependent variable of inflation, while the independent variables of Regional Minimum Wage (RMW) and Economic Growth (EG) have no effect. Inflation is significant to the dependent variable at the 5\% significance level, but these two independent variables have a significant effect on the $10 \%$ significance level.

\section{Concurrent Test / Overall (F-test)}

From the table above, it can be seen that the Prob (F-statistic) value is 0.00072 , less than $5 \%$, which means that the independent variables Population, Rice Price, RMW and EG simultaneously have a very significant effect on changes in the dependent variable of inflation. .

\section{Coefficient Determinant $\left(\mathbf{R}^{2}\right)$}

From table 3 , the $\mathrm{R}^{2}$ value is 0.662092 , indicating that the variation of the change in the value of the dependent variable INF can be explained simultaneously by the independent variables, namely the POPULATION, RICE PRICE, RMW, and ECONOMIC GROWTH variables of $66.21 \%$ while the remaining $33,79 \%$ were explained by other factors not included in the model. 


\section{Classic Assumption Test \\ Heteroscedasticity Test}

Table 4. Heteroscedasticity Test Results

\begin{tabular}{|c|c|c|c|c|}
\hline \multirow{2}{*}{\multicolumn{5}{|c|}{ Dependent Variable: LOG(ABS(RESID?)) }} \\
\hline & & & & \\
\hline \multicolumn{5}{|c|}{ Method: Pooled Least Squares } \\
\hline \multicolumn{5}{|c|}{ Date: 10/05/19 Time: 00:36 } \\
\hline \multicolumn{5}{|l|}{ Sample: 20072017} \\
\hline \multicolumn{5}{|c|}{ Included observations: 11} \\
\hline \multicolumn{5}{|c|}{ Cross-sections included: 4} \\
\hline \multicolumn{5}{|c|}{ Total pool (balanced) observations: 44} \\
\hline Variable & Coefficient & Std. Error & t-Statistic & Prob. \\
\hline C & -1.028130 & 8.095813 & -0.126995 & +0.8997 \\
\hline LOG(PENDUDUK?) & -0.258780 & 1.201291 & -0.215419 & +0.8307 \\
\hline LOG(UMR?) & -0.200005 & 1.913376 & -0.104530 & +0.9173 \\
\hline LOG(BERAS?) & 1.433619 & 1.185116 & 1.209686 & +0.2343 \\
\hline LOG(PE?) & -0.196393 & 0.252973 & -0.776338 & +0.4426 \\
\hline \multicolumn{5}{|l|}{ Fixed Effects (Cross) } \\
\hline SIANTAR - C & \multicolumn{4}{|l|}{-1.060845} \\
\hline SIBOLGA - C & \multicolumn{4}{|l|}{-0.482652} \\
\hline MEDAN-C & \multicolumn{4}{|l|}{0.555824} \\
\hline SIDEMPUAN--C & \multicolumn{4}{|l|}{0.987673} \\
\hline \multicolumn{5}{|c|}{ Effects Specification } \\
\hline \multicolumn{5}{|c|}{ Cross-section fixed (dummy variables) } \\
\hline R-squared & 0.487357 & \multicolumn{2}{|c|}{ Mean dependent var } & -4.247235 \\
\hline Adjusted R-squared & 0.387676 & \multicolumn{2}{|c|}{ S.D. dependent var } & 1.146541 \\
\hline S.E. of regression & 0.897182 & \multicolumn{2}{|c|}{ Akaike info criterion } & 2.783849 \\
\hline Sum squared resid & 28.97765 & \multicolumn{2}{|c|}{ Schwarz criterion } & 3.108247 \\
\hline Log likelihood & -53.24467 & \multicolumn{2}{|c|}{ Hannan-Quinn criter. } & 2.904151 \\
\hline F-statistic & *4.889181 & \multicolumn{2}{|c|}{ Durbin-Watson stat } & 1.960503 \\
\hline Prob(F-statistic) & 0.000594 & & & \\
\hline
\end{tabular}

Source: Results with EViews 8.1

From the results of processing with Eviews 8.1 software in table 4. it is found that all the coefficients of the independent variables are significant, so it can be concluded that there is no violation of the heteroscedasticity assumption.

\section{Multicollinearity Test}

It is found that $\boldsymbol{R}_{1}^{2}=0.999345>\boldsymbol{R}_{2}^{2}=0.903510 ; \boldsymbol{R}_{3}^{2}=0.903720 ; \boldsymbol{R}_{4}^{2}=0.442361 ; \boldsymbol{R}_{5}^{2}=0.083571$, the fixed effect model does not contain multicollinearity

\section{Economic A priori Test Analysis (Direction and Significance)}

A priori economic test explains how the independent variable affects the dependent variable by looking at the probability value of the t-statistic value to see the level of 
significance and also the directional test of the coefficient value of each independent variable.

The Inflation Equation Model in North Sumatra is as follows:

LOG $($ Inflation $)=-91.76667+8.429256$ LOG (population) -2.302758 LOG $($ RMW $)+$ 4.738640 LOG (Price of Rice) -1.045921 LOG (E).G

\section{Influence of Independent Variables Total Population (Population)}

The estimation results produce the coefficient value for the Population independent variable of 8.429256 and it is positive. This means that the total population has a positive effect on the inflation rate in North Sumatra. The higher the population, the higher the inflation rate in North Sumatra. An increase in population by $1 \%$ will increase the inflation rate in North Sumatra by $8,429256 \%$ with the assumption that the other independent variables remain / ceteris paribus. Judging from the test results on the t-statistic value, the probability value is .0024 . This value is $<\alpha=5 \%$, which means that the Population variable has a significant effect on the inflation rate in North Sumatera at the $95 \%$ or $90 \%$ confidence level.

The increase in population in the North Sumatera region will result in an increased inflation rate, this is due to an increase in the amount of public consumption. Commodities that are consumed are not only goods, but also in the form of services. This condition can actually have a positive impact, if it is responded and addressed properly. An increase in population will increase consumption, this is an opportunity for the real sector to increase goods to be produced. The increase in the number of goods and services that will be produced means an increase in the amount of labor used which will ultimately reduce unemployment. But if the increase in consumption due to an increase in population is not accompanied by an increase in production this will cause Demand Pull Inflation (demanddriven inflation)

The consumption variable itself has very little effect and is getting smaller until the last period. In the short term, shocks to consumption will only have an impact on inflation of 4.042408 percent. In the medium-long term, shocks to consumption are not more than 3 percent.

The Influence of Variable Free Regional Minimum Wages (UMR)

The estimation results produce a coefficient value for the UMR independent variable of -2.302758 and it is negative. This means that the UMR has a negative effect on the Inflation Rate in North Sumatra. The higher the UMR, the lower the inflation rate in North Sumatra. An increase in the UMR by $1 \%$ will reduce the inflation rate in North Sumatra by $2.302758 \%$ with the assumption that the other independent variables remain / ceteris paribus. Judging from the test results on the t-statistic value, the probability value is 0.03478 . This value is $<\alpha=5 \%$, which means that the UMR variable has a significant effect on the inflation rate in North Sumatra at the $95 \%$ or $90 \%$ confidence level.

Increasing the number of UMR in the North Sumatra region will cause the inflation rate to decrease, this is due to an increase in the amount of public consumption. Commodities that are consumed are not only goods, but also in the form of services. This condition can actually have a positive impact, if it is responded and addressed properly. An increase in population will increase consumption, this is an opportunity for the real sector to increase goods to be produced. The increase in the number of goods and services that will be produced means an increase in the amount of labor used which will ultimately reduce unemployment. But if the increase in consumption due to an increase in population is not accompanied by an increase in production this will cause Demand Pull Inflation (demanddriven inflation) 
The consumption variable itself has very little effect and is getting smaller until the last period. In the short term, shocks to consumption will only have an impact on inflation of 4.042408 percent. In the medium-long term, shocks to consumption are not more than 3 percent (Dwijawaty, 2015).

\section{The Effect of Independent Variables on Rice Price}

The estimation results produce the coefficient value for the rice price independent variable of 4.738640 and is positive. This means that the price of rice has a positive effect on the inflation rate in North Sumatera. The higher the price of rice, the higher the inflation rate in North Sumatera. An increase in rice prices by $1 \%$ will increase the inflation rate in North Sumatra by $4,738640 \%$ with the assumption that the other independent variables remain / ceteris paribus. Judging from the test results on the $\mathrm{t}$-statistic value, the probability value is 0.0023 , this value is $<\alpha=5 \%$, which means that the rice price variable has a significant effect on the inflation rate in North Sumatera at the 95\% confidence level.

Rice is the staple food in North Sumatera, it is only natural that a significant increase in rice prices will cause an increase in other staple foods in North Sumatra. The dependence of the people of North Sumaetra is also due to the culture of the people who make rice the main carbohydrate fulfillment.

The price of rice commodities also continues to soar. The dominant factor causing the soaring price of rice is the lack of rice supply due to crop failure due to weather disturbances in a number of rice centers in North Sumaetra, such as Simalungun, Langkat, Deli Serdang, and Serdang Bedagai. The lack of rice supply was also allegedly caused by the rice distributors who carried out hoarding. On the other hand, the high price of rice in the market is because the purchase price from refineries is also expensive. This is because the price of grain from farmers is also expensive (Bank Indonesia, 2010).

Unidirectional research has also been conducted, the results are short-term (in 2001: 1 2001: 4) most expenditure groups have no significant effect on the inflation rate at the 5\% level, meanwhile, in the long run (most expenditure groups have a significant inflation rates in Medan cities such as processed food, beverages, cigarettes and tobacco; housing, water, electricity, gas and fuel; clothing, and health, while the education, recreation and sports group and the transportation, communication and financial services group did not have a significant effect on inflation. in the city of Medan. (Fitrawaty, 2018).

Head of BPS Suhariyanto said the foodstuff group was contributed by the increase in the price of shallots and rice prices. The price of rice rose slightly but contributed to inflation by $0.03 \%$. We know that heavy weight is high, so even though the slight increase contributes to $0.03 \%$, said Suhariyanto at Statistics Indonesia Head Office, Central Jakarta, Perum Bulog must continue to carry out market operations so that rice prices remain stable and do not have a big impact on inflation in December (Siharapanku, 2018).

From the above, it can be concluded that the price of rice is influenced by the availability of rice from the supply side, weather conditions that cause crop failure, hoarding of rice by agents and high prices of rice from refineries.

\section{The Influence of Free Variables on Economic Growth}

The estimation results produce a coefficient value for the independent variable of economic growth of -1.045921 and it is negative. This means that economic growth has a negative effect on the inflation rate in North Sumatera. The higher the rate of economic growth, the lower the inflation rate in North Sumatera. An increase in economic growth by $1 \%$ will reduce the inflation rate in North Sumatera by $1.045921 \%$ with the assumption that the other independent variables remain / ceteris paribus. Judging from the test results 
on the t-statistic value, the probability value is 0.1985 . This value is $<\alpha=5 \%$, which means that the economic growth variable does not have a significant effect on the inflation rate in North Sumaetra at the $95 \%$ confidence level.

Inflation fluctuation in North Sumatera was not influenced by previous economic growth. This fluctuation is more influenced by the price of rice as a staple food and the population in North Sumatra. Fundamental factors, such as the interaction between supply and demand, influence the inflation rate more. Bank Indonesia as the authority for targetting inflation also does not make economic growth the basis for decision making.

North Sumatera's inflation in the first quarter of 2019 decreased compared to the previous period. The realization of inflation in the first quarter of 2019 was $1.05 \%$ (yoy). The foodstuff group contributed to annual deflation in the first quarter of 2019. Entering April, inflationary pressures increased again, far above the historical average. Going forward, inflation in the second quarter of 2019 is expected to increase compared to the previous quarter, in line with the entry of the month of Ramadan and Eid HBKN. The economy of North Sumaetra Province is predicted to chart moderate growth in the third quarter of 2019 amidst inflationary developments that have picked up again from the previous quarter. The economic moderation stemmed from the return to normal household demand after the Ramadan and Eid al-Fitr periods, amidst stable investment and improving net exports. Meanwhile, the rate of change in prices in general is still increasing as a result of increased inflationary pressure for seasonings, clothing, and the transportation, communication and financial services group (Bank Indonesia, 2019).

The fluctuation of the inflation rate in the 2010-2017 period means that it is more influenced by fundamental things, such as household consumption and the availability of staple foods, and other things, which are short-term, meaning that economic growth will affect inflation in the long run.

\section{CONCLUSION}

Inflation in North Sumatera is a type of inflation, the causes of which are fundamental things, such as the interaction of demand and supply. Therefore, to overcome this, the availability of stock of basic commodities, for example rice, must continue to be considered.

Policies and regulations on population control, such as those that have been implemented by National Family Planning Coordinating Board, must be continuously disseminated to the public.

Socialization and counseling on cropping patterns, how to grow crops for food crops, applying effective fertilizers to farmers to increase production. The community should pay attention to their consumption patterns, by prioritizing needs rather than wants, so that they do not behave beyond their limits.

\section{ACKNOWLEDGMENTS}

The author thank God Almighty for His blessings and guidance so that the writing of this article can be completed. I also express my gratitude to Rector of State University of Medan (Unimed) and the Dean of the Faculty of Economics, Unimed, for the assistance provided by the university's internal research funds, to increase knowledge so that this article becomes more interesting. Furthermore, the authors also thank family and colleagues, for their extraordinary contributions so that this article can be more perfect. 


\section{REFERENCES}

Agus Widarjono. (2009). Ekonometrika Pengantar dan Aplikasinya, Edisi Ketiga. Yogyakarta: Ekonesia

Annual Report UNDP Indonesia, Tahun 2013-2014.

Badan Pusat Statistik. (2018). Produk Domestik Regional Bruto (PDRB) kabupaten/kota tahun 2013-2017. Jakarta: Badan Pusat Statistik

Capello, Roberta. (2007). Regional Economics, Routledge. New York, Routledge.

Gujarati, Damodar. (2003), Ekonometri Dasar. Terjemahan: Sumarno Zain, Jakarta: Erlangga.

Kementerian Keuangan. (2017). Rincian Alokasi Dana Alokasi Umum dan Tambahan Dana Alokasi Khusus Fisik Menurut Provinsi/Kabupaten/Kota Dalam APBN-P TA 2017. Jakarta:Kementerian Keuangan

Kuncoro, Mudrajad. (2004). Analisis Spasial dan Regonal. Yogyakarta: AMP YKPN

Maipita, Indra, (2013), Memahanmi dan Mengukur Kemiskinan, Cetakan I, Penerbit Absolute Media, Yogyakarta.

Prawoto. N. (2009). Memahami kemisikinan dan strategi penanggulangannya, Jurnal Ekonomi dan Studi Pembanngunan, Vol 9, Nomor 1, April 2009: 56-69.

Ranis and Stewart. (2000). Economic Growth and Human Development. Jurnal World Development. Vol, 28. No, 2: 197-219.

Sjafrizal. (2008). Pertumbuhan Ekonomi dan Ketimpangan Regional Wilayah Indonesia Bagian Barat, Jakarta, Jurnal Buletin Prisma. 